\title{
Field production of kale (Brassica oleracea var. Acephala) with different nutrition sources
}

\author{
Mora-Bautista, Marco A. ${ }^{1}$; Rodríguez-Mendoza, María de las Nieves ${ }^{1}$; García-Cué, José Luis ${ }^{2}$; \\ Sánchez-Escudero, Julio ${ }^{3}$; Etchevers-Barra, Jorge D. ${ }^{1}$ \\ 1 Postgrado de Edafología. Colegio de Postgraduados, Montecillo Edo. de México. \\ 2 Postgrado de Socioeconomía, Estadística e Informática. Colegio de Postgraduados, Montecillo Edo. de \\ México. \\ 3 Postgrado de Agroecología y Sustentabilidad. Colegio de Postgraduados, Montecillo Edo. de México. \\ * Correspondence: marinie@colpos.mx
}

\begin{abstract}
Objective: Quantify the development and production of kale (Brassica oleracea var. Acephala cultivar "dwarf blue curled") in field conditions with organic and mineral fertilization.

Design/methodology: Kale was sown in a field in a completely rando design with five treatments and five repetitions per treatment (mineral soil fertilization, organic soil fertilization, mineral soil fertilization and foliar fertilization, organic soil fertilization and foliar fertilization and a control). After transplanting (dat) every 15 days in situ, the number of leaves was quantified and the phenological stages of the crop were identified. At 116 dat, with destructive sampling, the number length, fresh weight, resistance to penetration and ascorbic acid content in the kale leaves were quantified.

Results: The growth kinetics of the plants in the organic soil and foliar fertilization excelled, compared to the other treatments. In the cuttings, 1.5 to 3 bunches per plant were obtained, the resistance increased in leaves with organic products. Ascorbic acid increased in the leaves with all fertilizations.

Limitations implications: limited knowledge in the crop's management.

Conclusions: Kale is a crop that responds to different fertilization sources. Organic soil and foliar fertilization are alternatives for kale agroecological production, It's a vegetable scarcely grown in Mexico. The crop can be produced in the Texcoco area.
\end{abstract}

Keywords: Kale, organic fertilization, mineral fertilization, ascorbic acid.

Gitation: Mora-Bautista, M. A. Rodríguez-Mendoza, M. de las N., García-Cué, J. L., Sánchez-Escudero, J. \& Etchevers-Barra, J. D. (2021) Field production of Kale (Brassica oleracea var. Acephala) with different nutrition sources. Agro Productividad. https://doi. org/ 10.32854/agrop.v14i10.1954

Editor in Chief: Dr. Jorge Cadena Iñiguez

Received: April 13, 2021. Accepted: September 21, 2021.

Published on-line: November 8, 2021

This work is licensed under a Creative Commons Attribution-NonCommercial 4.0 International license.

\section{INTRODUCTION}

The kale (Brasica olereacea var. Acephala) is a vegetable with production potential and little known in Mexico; its consumption has not yet been generalized among the population. Called cabbage or kale, a green leafy vegetable, belongs to the Brasicaceae family such as cabbage, broccoli, cauliflower, and Brussels sprouts (Samec et al., 2019). Due to its high phytochemicals content, it is an important source of secondary metabolites (Reyes-Munguía et al., 2017), and is characterized by a high antioxidants content such as flavonoids $(73 \mathrm{mg} / 100 \mathrm{~g})$, glucosinolates (100.7 $\mathrm{mg} / 100 \mathrm{~g}$ ), carotenoids, and others (19.61 mg/100 g). It is a vitamin $\mathrm{C}$ source $(120 \mathrm{mg} / 100 \mathrm{~g})$, provitamin A,

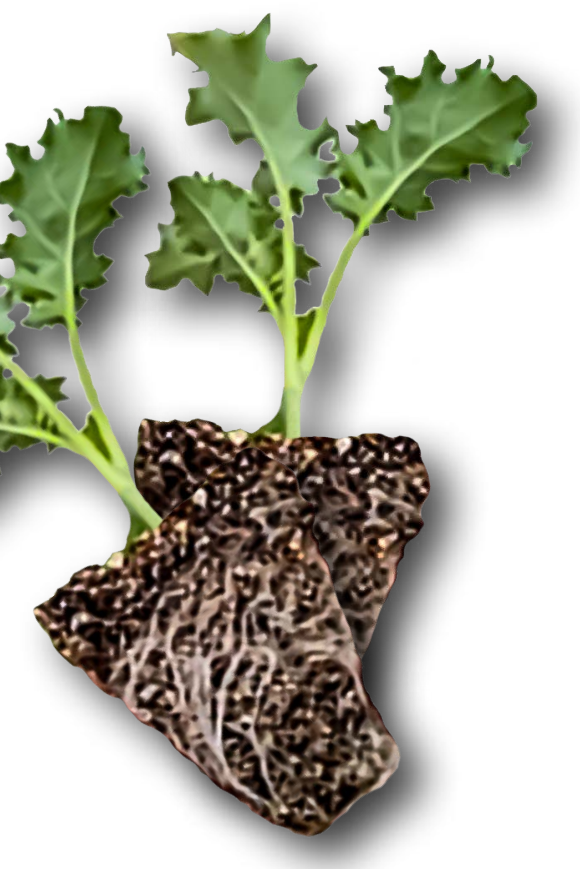


vitamin $\mathrm{K}, \mathrm{B} 6$, folic acid, thiamine, riboflavin, pantothenic acid, vitamin $\mathrm{E}$ (Samec et al., 2019: USDA, 2016), and minerals such as iron $(1.47 \mathrm{mg} / 100 \mathrm{~g})$, zinc $(0.56 \mathrm{mg} / 100 \mathrm{~g})$, manganese $(0.659 \mathrm{mg} / 100 \mathrm{~g})$, calcium $(150 \mathrm{mg} / 100 \mathrm{~g})$ and magnesium $47 \mathrm{mg} / 100 \mathrm{~g})$ (USDA, 2016) and It only contributes $49 \mathrm{kcal} / 100 \mathrm{~g}$.

The few kale crops in Mexico, such as those at the "chinampera" area of Xochimilco (Figure 1), are produced with mineral fertilizers using potentially toxic chemical substances, contrary to their nutritional characteristics. Among the main problems for this crop are aphids (Brevicoryne brassicae) when crops are developed for leaves cutting.

However, it is possible to produce kale in harmony in a sustainable way using an agroecological system, by changing some of the limitations of conventional ones. This includes a set of practices that promote the proliferation of life throughout the plot, promoting the organic fertility of the soils, plant biodiversity and ecosystemic functions (Restrepo, 2013).

Kale leaves are sold in gourmet and organic markets, in six leaves bunches, their cost between $\$ 30$ and $\$ 45$ Mexican pesos, or $\$ 150.00 \mathrm{~kg}$. The marketed leaves must be firm and green, without brown edges, an indication of old leaves that should not be consumed, according to the US standard (USDA, 2015). This research aimed to quantify the production and quality of kale produced in the field depending on the sources of fertilization and the application.

\section{MATERIALS AND METHODS}

The research was established in the Agroecology and Sustainability module, Colegio de Postgraduados campus Montecillo at the Estado de México (19²7'38” N, 98 54' $11^{\prime}$ ' W). The predominant climate is temperate semi-dry, with an average annual temperature and precipitation of $15.9^{\circ} \mathrm{C}$ and $686 \mathrm{~mm}$, each (SMN, 2020). Seeds of kale cv "dwarf blue curled", Itsco ${ }^{\circledR}$ seedbed, were sown in a seedbed in an equal parts mixed substrate of peat moss $\left(\right.$ Promix $\left.^{\circledR}\right)$, perlite $\left(\right.$ Agrolita $\left.^{\circledR}\right)$ and vermiculite $\left(\right.$ Termita $\left.^{\circledR}\right)$. When plants had $10 \mathrm{~cm}$ height and four true leaves (Figure 2), they were transplanted to plots in the field.

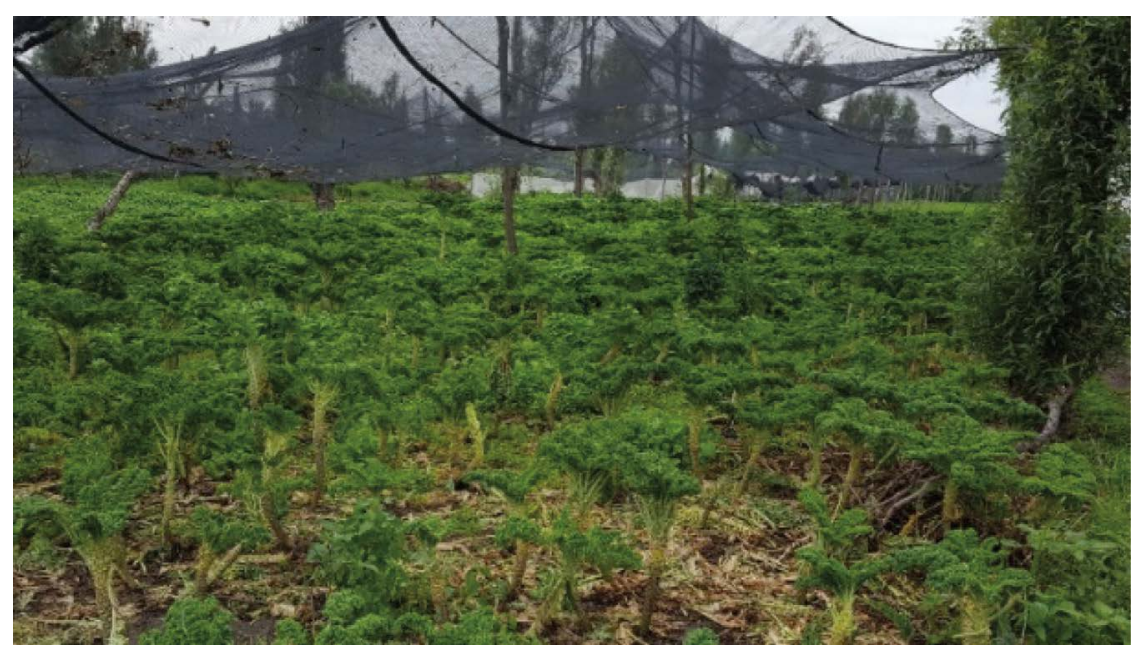

Figure 1. Kale production in chinampas of Xochimilco, Mexico City. 

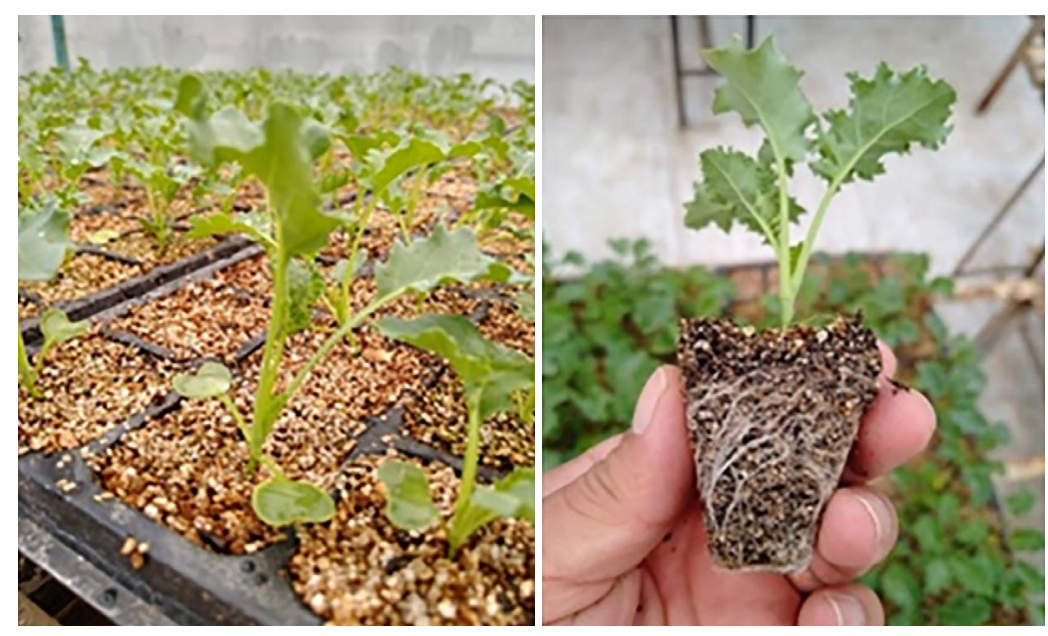

Figure 2. Kale seedling and seedling production.

At field conditions, the plants were subjected to five treatments (Table 1). Each treatment was replicated five times. The crop was sprinkled watered. The experimental design was of completely randomized plots (DCA). The experimental unit, a plot, consisting of 16 plants at a $0.60 \mathrm{~m}$ distance between plants and between rows, in an offset "tresbolillo" arrangement.

Kale is a rarely sown crop in Mexico and therefore has no generalized recommendation for soil mineral fertilization, an equivalent dose to 250-120-100 kg ha of N P K was used for soil mineral fertilization, following recommendations for broccoli (INIFAP, 2008). The sources were urea, DAP (diammonium phosphate) and potassium nitrate. For mineral foliar fertilization, Bayfolan ${ }^{\circledR}$ product from Bayer was applied every 15 days after transplant in a $3 \mathrm{~L}$ ha dose. The organic fertilization treatment consisted in applying $4 \mathrm{t}$ ha of a sheep vermicompost mixture $(\mathrm{C} / \mathrm{N}$ ratio 13:1 with 60 days maturity) obtained from the production module of the Agroecology and Sustainability Postgraduate Program. Also, basalt rock flour (BASAGRO) in a 10:1 ratio (vermicompost: rock flour) was included. For foliar organic fertilization, a fermentation of activated mountain microorganisms was used (Castro 2014).

During the kale growth, in the field, different agroecological products were applied, depending on the pests or diseases present. Coconut biozyme was applied as an enzyme activator, calcium sulfide broth to control fungi, and chili, garlic and rue extracts for

Table 1. Established treatments to assess the effect of organic and mineral fertilization on the development and production of kale (Brassica oleracea var. Acephala auct.) in the field.

\begin{tabular}{c|l|c}
\hline Treatment & \multicolumn{1}{|c}{ Description } & Abbreviation \\
\hline 1 & Control & T \\
\hline 2 & Organic fertilization to the soil & FOS \\
\hline 3 & Mineral fertilization to the soil & FOS +FFO \\
\hline 4 & Organic fertilization to the soil + organic foliar fertilization & FMS +FFM \\
\hline 5 & Mineral fertilization to the soil + mineral foliar fertilization & \\
\hline
\end{tabular}


whiteflies and aphids control. The definition of the phenological stages of kale was based on the plants' physical and physiological changes, from the seed germination until the appearance of the flowers (reproductive stage), registering the dates these were observed.

From transplant to final sampling, the number of leaves per plant was counted (in situ) every 15 days to know the kinetics and identify the moment of maximum leaf production per plant. At 116 days after transplant (dat), a destructive sampling was done to assess the leaf production. For this, a scale of sizes (in $\mathrm{cm}$ ) of the leaves was designed: 4 to 10 , 10.1 to $15,15.1$ to $20,20.1$ to $25,25.1$ to $30 \mathrm{~cm}$ and 30.1 to $35 \mathrm{~cm}$. Each treatment's commercial yield per cut was obtained, with their leaves of size (20 to $35 \mathrm{~cm})$ and their fresh weight. The firmness or resistance to penetration of the leaves was evaluated with a penetrometer, Grainger 5DPK3 brand, for fruits. The values were reported in $\mathrm{kg}$ of force. The ascorbic acid (vitamin $\mathrm{C}$ ) content was determined with the 2,6-dichloroindophenol method (AOAC, 1998). The data obtained from the variables under study were subjected to a test for normality. The data were subjected to an analysis of variance (ANOVA) with its corresponding homogeneity of variances tests, independence and normality in the residuals, finally, the Tukey's means comparison tests were performed with an $\alpha=0.05$ level significance. The calculations were supported by the statistical package SAS V9.4 for Windows.

\section{RESULTS AND DISCUSSION}

The maximum leaf number per plant during the period in which the field experiment was carried out (October 2019-February 2020) was obtained in the penultimate cut at 101 dat (Figure 3). The treatments with the highest number of leaves were organic soil fertilization + organic foliar fertilization (OSF + OFF) with 44.6 leaves, followed by mineral soil fertilization + mineral foliar fertilization $(\mathrm{MSF}+\mathrm{MFF})$ treatment, which had an average of 41.2 leaves. In both cases, a higher production compared to the control $(\mathrm{T})$ with 38.5 average leaves.

The crop treated with organic soil fertilization + organic foliar fertilization (OSF $+\mathrm{OFF})$, increased leaf production by $13.7 \%$ in the greater plant development stage (penultimate sampling), compared to the mineral soil fertilization treatment + mineral foliar fertilization (MSF + MFF). Applying organic fertilizers to soils has been shown to increase crop productivity and improve soils (Lazcano et al., 2012). In this experiment, organic fertilization applied to the soil as vermicompost and organic foliar increased the number of leaves per plant (Figure 3), compared to mineral fertilization. These results relate to the benefits of vermicompost in the production of vegetables in fields reported by Dinesh et al. (2010). These authors indicate that with this strategy the microbial activity of the soil increased by $16 \%$, and with it, the enzymatic activity, and the release of essential macronutrients for plants. Lisiewska et al. (2008) reported 25 and 30 leaves per plant production at 70 dat. In our experiment at Montecillo, the average leaves number at 70 dat was 33 to 39, higher than that reported by the above-mentioned authors. This indicates that kale responds to both tested sources of fertilization. The plant development was fast and the crop's evolution was observed in a short time (Figure 4). 


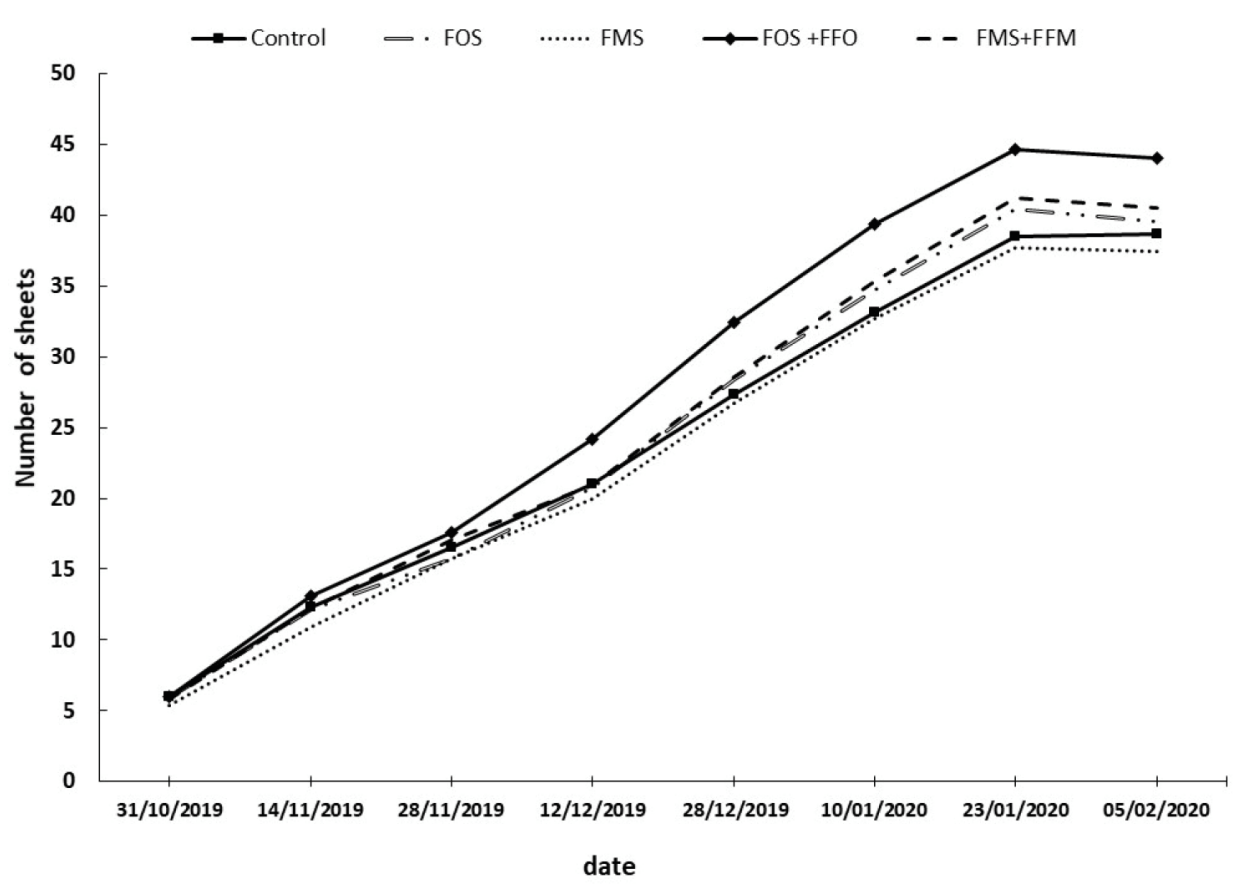

Figure 3. Growth kinetics of kale leaves (Brassica oleracea var. Acephala auct.) Per plant at 116 dat under five fertilization treatments: TEST $=$ Control; FOS $=$ organic fertilization to the soil; $\mathrm{FMS}=$ mineral fertilization to the soil; FOS + FFO= organic fertilization to the soil and foliar; FMS + FFM=mineral fertilization to the soil and foliar.

In Texas, the maximum production of kale leaves occurs at 90 dat, when the harvest begins, with yields of 5 to $6 \mathrm{t} \mathrm{ha}^{-1}$ (Masabni, 2011). In this experiment, the first cut was made at 88 dat and the maximum leaf production was reached at 101 dat, with yields of $5 \mathrm{t}$ $\mathrm{ha}^{-1}$ only considering the leaves of 20-30 cm long intervals that, commercially, are the best.

From the assessed phenological stages, the vegetative stage is the most important for horticultural producers (Fuentes and Pérez, 2003), if the phenology of cabbage (Brassica oleracea var. Capitata) is taken as a reference since there is no reported phenological scale for kale. We propose six stages, a product of our observations of the species under field conditions (Figure 5).

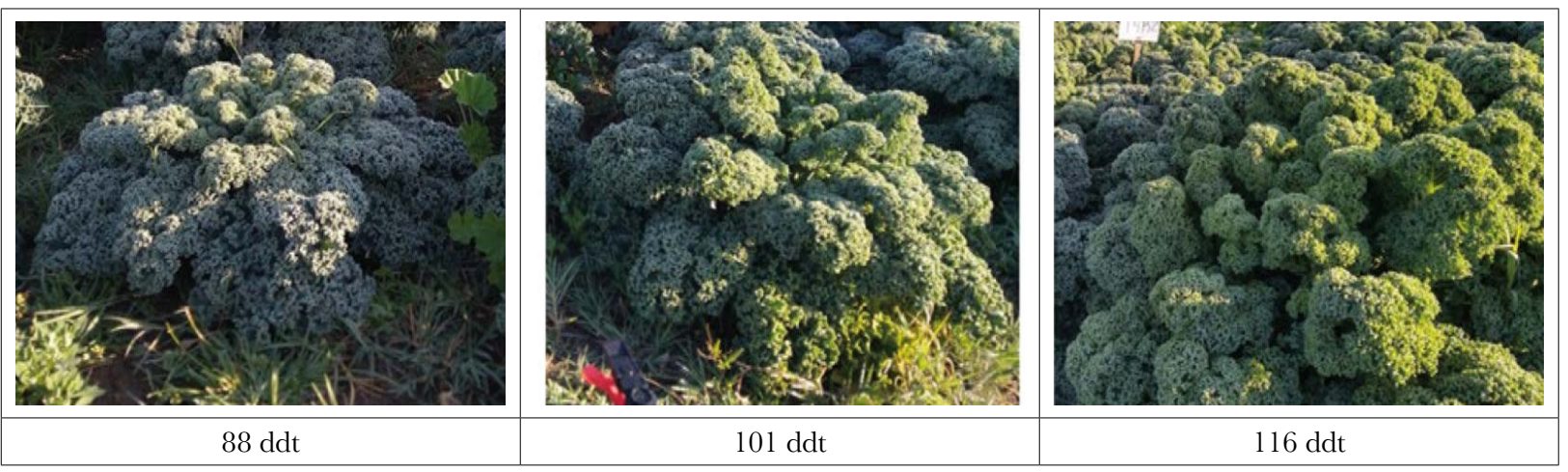

Figure 4. Kale cultivation and development in field conditions on three sampling dates. 


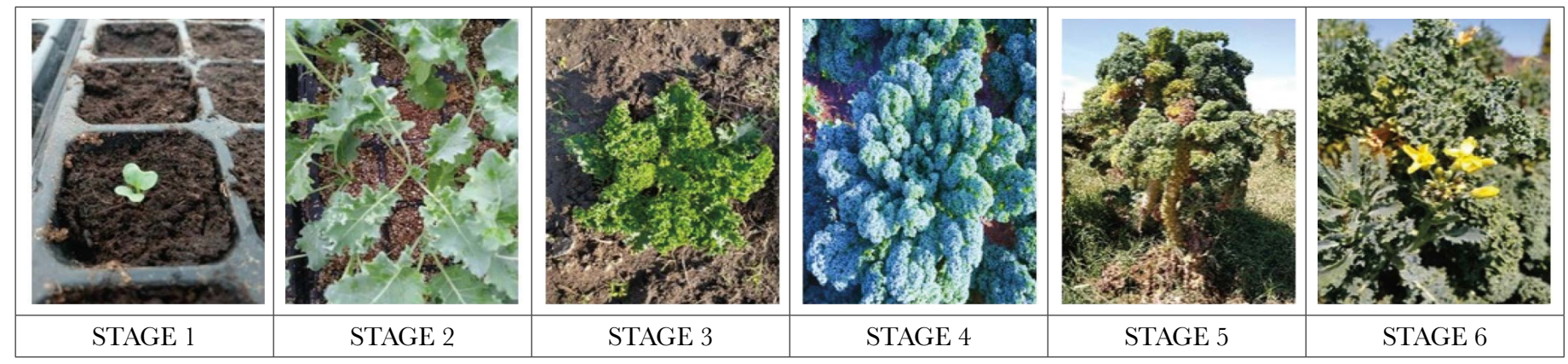

Figure 5. Phenological stages of kale cultivation in the field (Brassica oleracea var. Acephala).

Stage 1: seed imbibition until cotyledons (seedling) emerge. It occurs from 7 to 10 days. Stage 2 (seedling): begins after the emergence of the cotyledons and ends when the plant has between four to five true leaves (30 days). During this stage, the plants develop their root system and their first true leaves. There is a dull green hue and the leaves begin to present the characteristic kale curl; there is the presence of wax in the cuticle of the leaves, characteristic of brassicas. Stage 3 (vegetative development): starts from transplant to when they have ten to 14 leaves after transplanting, the plants enter a process of rapid biomass increase. The leaf area rapidly increases as well as the root system and the stem. Between 30 and 90 dat, an intense lemon green hue predominates in the leaves and the curling is more consistent. Stage 4 (maximum growth): the plant continues to produce leaves until it reaches its maximum production, that is, 30 to 45 leaves. The appearance rate is six to eight leaves per week. In this period the harvest begins, between 90-120 dat. The tonality of the leaves is an ashy bluish green according to the variety and the curling is intense. Stage 5 (plateau): in this stage, the production of leaves stabilizes, there is no accelerated growth. Harvesting may continue during this stage. From 130-260 dat. The old leaves located at the base of the plant show yellowing. At this point, the plant has the appearance of a palm tree. Stage 6 (reproductive): the plant requires low-temperature stimuli that activate the physiological processes that culminate in the production of inflorescences that are yellow typical of brassicas. From 260-280 dat (Figure 6).

Waterland et al. (2019) proposed a phenological classification of kale that consists of only five stages. It begins with an expansion stage of the cotyledon leaves until the presence of eight leaves (approximately 50 days after emergence), from then to an adult plant and flowering is not considered.

The six-length intervals of the leaves proposed in Materials and Methods were recorded. From 4 to $10 \mathrm{~cm}$ up to the commercial size of 20 to $35 \mathrm{~cm}$. Fresh commercial-size leaves are heavy, so they are sold in bundles of six leaves or per kilo. This vegetable is usually found in agroecological and organic markets and some supermarkets with gourmet vegetables. For consumers, the cost of a bunch is between $\$ 30$ and $\$ 45$ Mexican pesos and the kilo between $\$ 120$ and $\$ 150$. However, the intermediaries buy bunches from producers at $\$$ 5.00 and kilos between $\$ 25$ to $\$ 30$. Only when producers directly sell to the consumer can they get a little more for their production. In the present experiment, the five treatments 


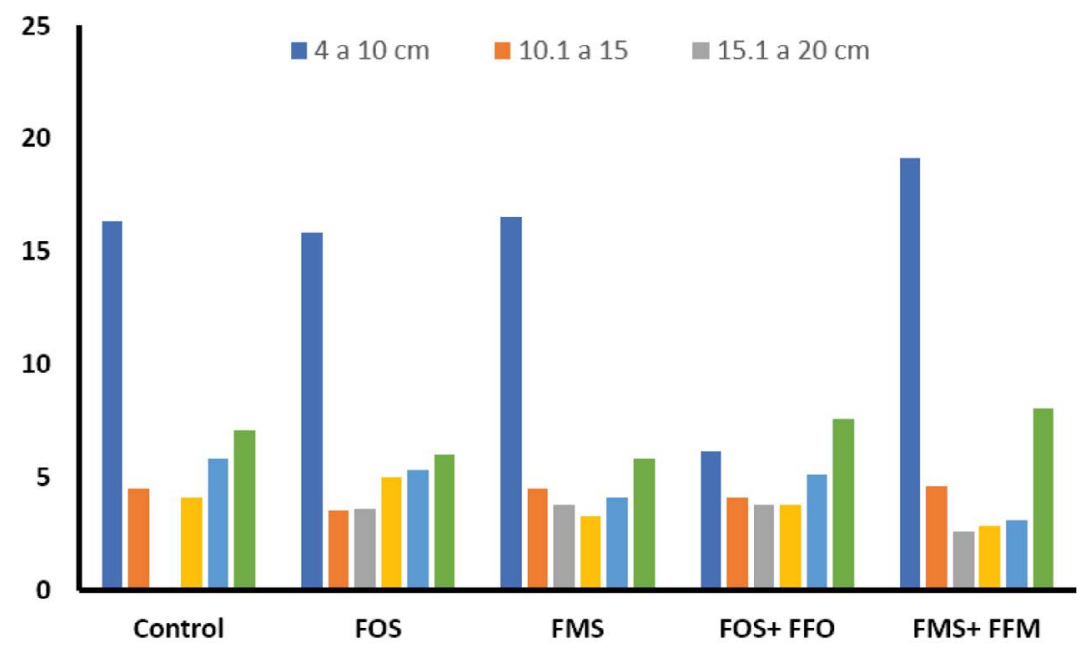

Figure 6. Leaves number per length interval produced per plant with different sources of nutrition at 116 dat.

presented the same trend of the length of the leaves per interval, except for the plants treated with organic fertilizer applied to the soil plus organic foliar fertilizer, the smaller leaves were less (Figure 6).

The leaves of between 20 and $30 \mathrm{~cm}$ are the most commercial, found in greater quantity in the control treatment and those where organic fertilization was applied to the soil and the combination to the soil and organic foliar fertilization. In the control and those that were applied to foliage, the number of leaves increased from 30.1 to $35 \mathrm{~cm}$. By analyzing the number per interval, it is possible to divide it into commercial and non-commercial leaves to calculate the income from production, as indicated in Table 2.

Twelve to fifteen percent of the leaves turn out to be non-commercial. With the quantified commercial leaves, the number of bunches per plant was obtained and adjusted to a hectare consisting of 27,500 plants per ha (this value was obtained as a function of the distance sown in the experiment). The number of bunches varied from 1.82 (mineral fertilization to the ground and foliar) to 2.83 (control) and the production per plant from $\$ 9.1$ to $\$ 14.5$ from their sale to intermediaries

The income per hectare calculation ranged from $\$ 250,250$ to $\$ 389,125$. It seems an acceptable amount for a single cut; however, this crop requires a lot of labor for each cut, which on average it must be done every 7 days from 90 to 100 days, which is the

Table 2. Yield (g) of commercial leaves, number of bunches and income from kale leaves cuttings per plant and hectare developed with different sources of nutrition.

\begin{tabular}{l|c|c|c|c|c|c}
\hline \multirow{2}{*}{ Treat. } & \multicolumn{3}{|c|}{ Yield (g/ plant) } & Commercial leaf $/$ & $\begin{array}{c}\text { Bunch/ } \\
\text { plant/ha }\end{array}$ & $\begin{array}{c}\text { Income/ } \\
\text { plant/ha \$ }\end{array}$ \\
\cline { 2 - 4 } Control & No commercial & Commercial & Total & 17.0 & $2.83 / 77,825$ & $14.15 / 389,125$ \\
\hline FOS & 35.9 & 868.5 & 904.4 & 16.3 & $2.71 / 74,525$ & $13.55 / 372,625$ \\
\hline FMS & 124.9 & 1006.5 & 1131.4 & 13.2 & $2.2 / 60,500$ & $11 / 302,500$ \\
\hline FOS+FFO & 152.6 & 746.4 & 899 & 16.5 & $2.75 / 75,625$ & $13.75 / 378,125$ \\
\hline FMS+FFM & 114.6 & 962.4 & 1077 & 10.9 & $1.82 / 50,050$ & $9.1 / 250,250$ \\
\hline
\end{tabular}


maximum production. The plants in the control treatment were the ones that had more commercial leaves, followed by the plants where organic fertilizer was applied to the soil and foliar, finally the treatments with mineral fertilization to the soil and mineral fertilization to the soil and foliar (Table 2). Our results differ from those reported by Antonious et al. (2014), who found a favorable response to any source of fertilization, organic or mineral, which caused an increased yield per plant and per hectare compared to plants without fertilization. Although the control plants are the ones that produce the greatest number of leaves, their resistance to penetration was the lowest $(7.51 \mathrm{~kg}$ force) compared to the leaves with organic fertilization to the soil and foliar $(7.92 \mathrm{~kg}$ force). The application of any source of nutrition favored the resistance to the penetration of the leaf, as it increased between $2.6 \%$ and $5.4 \%$ above the value of the leaves of the control plants without fertilizer. In the experiment, any source of nutrition increased resistance, which favors shelf life (Table 3).

All treatments where fertilizer was applied increased the vitamin C content (Table 3). The plants in the control treatment reported the lowest ascorbic acid values. The mineral fertilization treatment to the soil + mineral foliar fertilization increased ascorbic acid by $61 \%$ compared to the control. Aquino et al. (2011) indicate that the ascorbic acid content in brassicas is influenced by edaphoclimatic conditions and cultural practices. The ascorbic acid concentration in the two treatments with organic fertilization remained constant and exceeded that of the treatment with mineral fertilization to the soil. When foliar sources are applied, the ascorbic acid value increases, indicating that the plant responded to the application of nutrients. Nepomuseno et al. (2020) found $96.7 \mathrm{mg} / 100 \mathrm{~g}$ of fresh weight of this compound in 90-day-old kale leaves. In our research at 116 dat, the vitamin $\mathrm{C}$ content increased between 60 and $70 \%$.

\section{CONGLUSIONS}

Kale (Brassica oleracea var. Accephala) increases its development with the application of conventional or organic fertilizers. The application of organic fertilizers to the soil and foliar increases the formation of leaves throughout the development of the plant, compared to mineral fertilizers. The amount of ascorbic acid (vitamin $\mathrm{C}$ ) in kale leaves increases with the incorporation of organic and inorganic fertilizers. On average, a cut of leaves (20 to

Table 3. Resistance to penetration and ascorbic acid content in kale (Brasica oleracea var. Accephala) leaves of 116 dat developed with organic fertilization to the soil, mineral and foliar fertilization.

\begin{tabular}{l|c|c}
\multicolumn{1}{c|}{ Treatment } & $\begin{array}{c}\text { Penetration resistance } \\
(\mathbf{k g f})\end{array}$ & Ascorbic acid (mg/100g) \\
\hline Control & $7.51 \mathrm{a}$ & $147 \mathrm{c}$ \\
\hline FOS & $7.71 \mathrm{a}$ & $189 \mathrm{~b}$ \\
\hline FMS & $7.77 \mathrm{a}$ & $156 \mathrm{c}$ \\
\hline FOS+FFO & $7.92 \mathrm{a}$ & $199 \mathrm{~b}$ \\
\hline FMS+FFM & $7.73 \mathrm{a}$ & $238 \mathrm{a}$ \\
\hline
\end{tabular}

Values with different letters in each column represent statistical differences according to Tukey's test $(\mathrm{P}<0.05)$. 
$30 \mathrm{~cm}$ ) yields 1.5 to 3 bunches of six leaves per kale plant. The quality of the leaf and the nutritional content are a function of the application of fertilizers to the crop.

\section{REFERENGES}

Antonious, F. G, Turley T. E., Hill R. R., Snyder C. J. (2013). Chicken manure enhanced yield and quality of field-grown kale and collard greens. Journal Enviroment Science and Health 49:299-304. doi:10.1080/03 601234.2014 .868681

Association of Official Analytical Chemists- AOAC. (1998). Official Methods of Analysis of AOAC International II. Gaithersburg, Maryland, USA.

Aquino, A. C. M. S., Silva, M. H. M., Rocha, A. K. S., Castro, A. A. (2011) Estudo da influência de diferentes tempos e métodos de cocção na estabilidade dos teores de clorofila e ácido ascórbico em brócolis (Brassica oleraceae). Scientia Plena, 7:1-6.

Castro, B. L. (2014) ¿Cómo hacer microorganismos de montaña MM? Receta para productores. Lab. Microbiología Agrícola, Centro de Investigaciones Agronómicas. Universidad de Costa Rica. 12 de noviembre 2020. Disponible en:http://www.cia.ucr.ac.cr/pdf/Brochure-MicroCIA-VF-2017web.pdf

Fuetes, F., \& Pérez, J. (2003). Cultivo del repollo. Centro Nacional de Tecnología Agropecuaria y Forestal (CENTA). La libertad, El Salvador. p 36. Disponible en: http://www.centa.gob.sv/docs/guias/hortalizas/ Guia\%20Repollo\%202003.pdf

Dinesh, R., Srinivasan, V., Hamza, S., Manjusha, A. (2010) Short-term incorporation of organic manures and biofertilizers influences biochemical and microbial characteristics of soils under an annual crop Turmeric (Curcuma longa L.). Bioresour Technol 101:4697-4702

INIFAP. (2008). Brócoli. Recomendaciones de fertilización para mejorar la producción. Desplegable para productores No. 2. Campo Experimental Bajío. Km 6.5 Carr. Gelaya-San Miguel de Allende. C.P. 38110 Celaya Gto. México.

Junior, S.J., da Silva F.P., de Lima T C. A, Roggia Z. M., Dallacort, R., Pereira de L. P G.2019. ¿Does Knitted Shade Provide Temperature Reduction and Increase Yield Kale? Journal of Agricultural Science 11:10311.

Lazcano, C., Gómez-Brandón, M., Revilla, P. (2012). Short-term effects of organic and inorganic fertilizers on soil microbial community structure and function: A field study with sweet corn. Biology and Fertility of Soils. 49:723-73 doi:310.1007/s00374-012-0761-7.

Lisiewska, Z., Kmiecik, W., Korus, A. (2008). The aminoacid composition of kale (Brassica oleracea L. var. acephala), fresh and after culinary and technological processing. Food Chemistry, 108: 642-648.doi: 10.1016 / j.foodchem.2007.11.030

Masabni, J. (2011). Collards/Kale. Department of Horticulture. Texas AgriLife Extension Service. Disponible en: https://www.aggie-horticulture.tamu.edu/vegetable/files/2011/10/collardskale.pdf

Nepomuseno, T. A., Moraes, E. M., Ribeiro C. P. W., Macedo J. E. K., Klosowski E. S., Boes S. G. A., Vinicius B. A. (2020). Efeitos dos consórcios com quiabeiro nas características fisicoquímicas da couve de folha sob manejo orgánico. Braz. J. of Develop. Curitiba. 6:79987-80001.

Restrepo, R. J. (2013). Manual práctico: El ABC de la Agricultura Orgánica, fosfitos y panes de piedra. Impresión Feriva S.A. Santiago de Cali, Colombia. 396 pp

Reyes-Munguía, A., Rosas-Trejo, L., Campos-Montiel, R., Quintero-Lira, A., Carrillo-Inungaray M. L. 2017. Propiedades antioxidantes del extracto acuoso de Brassica oleracea var. Sabellica. Revista de Ciencias ambientales y Recursos Naturales 3:30-34.

SMN Servicio Meteorológico Nacional (2020). información estadística climatológica. https://smn.cna.gob.mx/ es/

USDA National Database for Standard Reference. (2016). Release 28, recuperado agosto 2020.

USDA 2015.United States Standards for Grades of Kale. Recuperado de https://www.ams.usda.gov/gradesstandards/kale-grades-and-standards

Waterland L. N., Moon Y., Tou C. J., Kospell D. A., Kim J. M., Park. S.(2019). Differences in Leaf Color and Stage of Development at Harvest Influenced Phytochemical Content in Three Cultivars of Kale (Brassica oleracea L. and B. napus). Journal of Agricultural Science 11:14-21. 